\title{
ADDITIONS TO THE FLORA OF THE KAIJENDE HIGHLANDS, PAPUA NEW GUINEA: GLOCHIDION WELZENII (EUPHORBIACEAE), A NEW SPECIES FROM THE PAIELA LIMESTONE DISTRICT
}

\author{
W. TAKEUCHI \\ Arnold Arboretum and the Herbaria of Harvard University, c/o PNG National Forest Authority, \\ P.O. Box 314, Lae, Morobe Province 411, Papua New Guinea
}

\section{SUMMARY}

Glochidion welzenii is described from the 2005 Kaijende Highlands Expedition. The microphyllous novelty is easily distinguished by its Phyllanthus-like aspect and solitary flowers.

Key words: Euphorbiaceae (s.1.), Glochidion, Pandanus, savannah.

\section{INTRODUCTION}

The New Guinea cordillera ranks with Costa Rica-Chocó, Atlantic Brazil, Andes Amazonia, and Northern Borneo, as one of the world's five principal centres for tracheophyte diversification (Barthlott et al. 1996, 2005). Particularly on the Indonesian side, many districts in central New Guinea consist of uninhabited wilderness and are collectively the largest intact repository for plant life in Papuasia.

As part of a long-term plan for documenting this resource, Conservation International and its partners are currently implementing a series of multidisciplinary surveys of the Dividing Ranges. The initiative straddles the Indonesia-Papua New Guinea (PNG) border, encompassing a floristic region suspected of harbouring large numbers of rare or undiscovered taxa. The 2005 Kaijende survey was the lead operation on the bi-national itinerary (see Richards 2007, for a comprehensive summary), and was immediately followed by the widely publicised Foja I Expedition to Irian Jaya. Two novelties in Euphorbiaceae were discovered during these initial explorations of poorly known environments (Takeuchi 2007), of which Glochidion welzenii is the first to be formally presented.

\section{DESCRIPTION}

Glochidion welzenii W.N.Takeuchi, spec. nov. - Fig. 1, 2; Map 1

Affinis G. dumicola Airy Shaw sed foliis obtusis (nec cuspidato-acuminatis) minoribus $(5-) 13-25(-33) \times(5-) 10-16(-20) \mathrm{mm}$; floribus masculis unifloris; capsulis trilobis differt. - Typus: Takeuchi, Towati \& Ama 20025 (holo LAE; iso A, L), Papua New Guinea, Enga Province, Paiela bivouac (Lake Tawa), alt. 2550 m, 1 September 2005. 


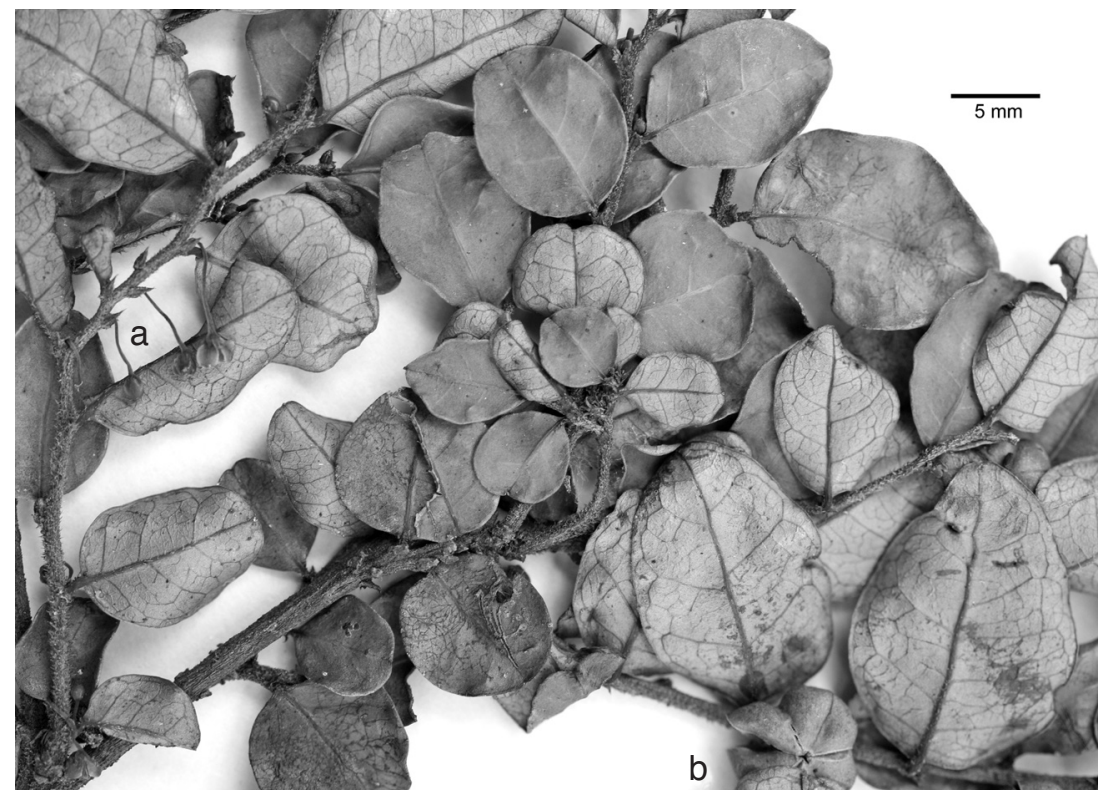

Fig. 1. Glochidion welzenii W.N.Takeuchi. Unmounted duplicate from Takeuchi, Towati \& Ama 20025. a. Staminate flowers; b. fruits.

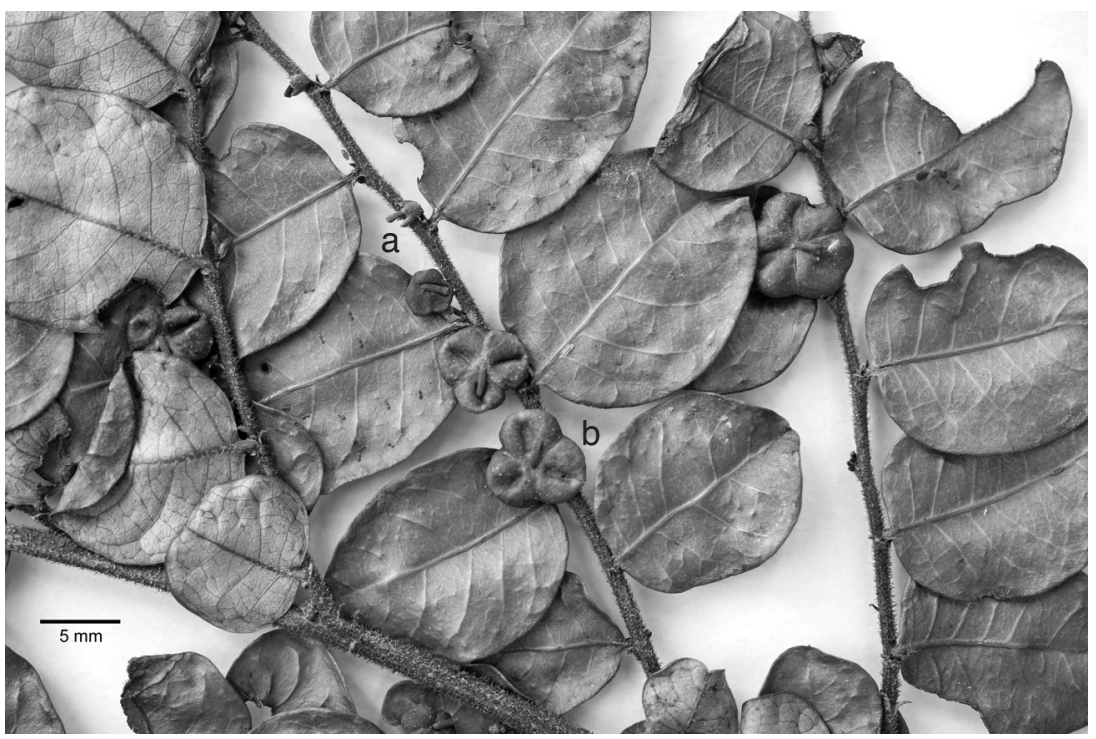

Fig. 2. Glochidion welzenii W.N.Takeuchi. Unmounted duplicate from Takeuchi, Towati \& Ama 19994. a. Pistillate flowers; b. fruits. 
Terrestrial shrubs 2-3 m tall, monoecious, without exudate. Branchlets terete, 0.6-1 mm subapical diam., obliquely ascending, straight (or fractiflex), lacking lenticels; younger surfaces nitid, black; older surfaces opaque, brunnescent; indument hirtellous, dense, reddish brown, hairs catenate, subulate or irregularly compressed, to c. $0.5 \mathrm{~mm}$ long, hair residue verruculose. Leaves distichous, crowded, spreading; stipules acuminate, $1.5-2$ by $0.5-1 \mathrm{~mm}$, paired, appressed or patent, persisting, initially with hairs as the branchlets, glabrescent; petioles $1-2$ by $0.3-1 \mathrm{~mm}$, planoconvex or cylindrical, black, glabrous; blades ovate, broadly elliptic (or orbicular), (5-)13-25(-33) by $(5-) 10-16(-20) \mathrm{mm}$, often asymmetrical, coriaceous to papery; surfaces bifacially green in vivo, drying brunnescent, ochraceous, greyish green, olivaceous, or fuliginous, adaxially glabrous, abaxially pilose on midrib; base rounded or subtruncate; margin entire; apex obtuse, mucronulate; venation reticulate-brochidodrome, secondaries $5-9(-11)$ per side, at the lamina centre straight-diverging $60-75^{\circ}$ from costae, medially arcuate, closing by inframarginal commissural nerves, anastomosing beyond the loops; veins adaxially planate or weakly raised, abaxially prominent, copiously areolate, reticulum manifest. Flowers axillary from foliate nodes, glabrous or nearly so, ebracteate, inconspicuous. Staminate flowers solitary, emerging from axils below the pistillate flowers, fulvous; pedicels filiform, flaccid, 6-9 mm long; sepals 6 (or 7), imbricate, biseriate, diverging, obtuse, unequal, outer lobes to c. 2.2 by $1.3 \mathrm{~mm}$, inner lobes to c. 1.9 by $1 \mathrm{~mm}$; stamens 3, filaments obsolete, anthers syngenesious, oblongoid, 0.8-1 mm long, longitudinally dehiscent, connectives distally conoid-appendiculate; pistillode absent. Pistillate flowers from upper axils, solitary, black, subsessile or 0.5-1(-2) mm pedicellate; sepals 3-5, ovate, 1.2-1.5(-1.8) $\mathrm{mm}$ long, erect, enclosing the ovary, fimbriate or not; gynoecium superior, smooth; ovary globular, 0.6-0.9 mm diam., lobes 3, each locule bi-ovulate, placentation apical-axillary; style columnar, $1.7-2.3$ by $0.2-0.3 \mathrm{~mm}$, erect, \pm completely exserted, subapical interval hollow, often clavately expanded, summit truncate or obscurely 2-denticulate. Fruits capsular, inserted on accrescent pedicels to $3 \mathrm{~mm}$ long, globose-discoid, 2.5-3 by (6-)7-8.5 $\mathrm{mm}$, red,

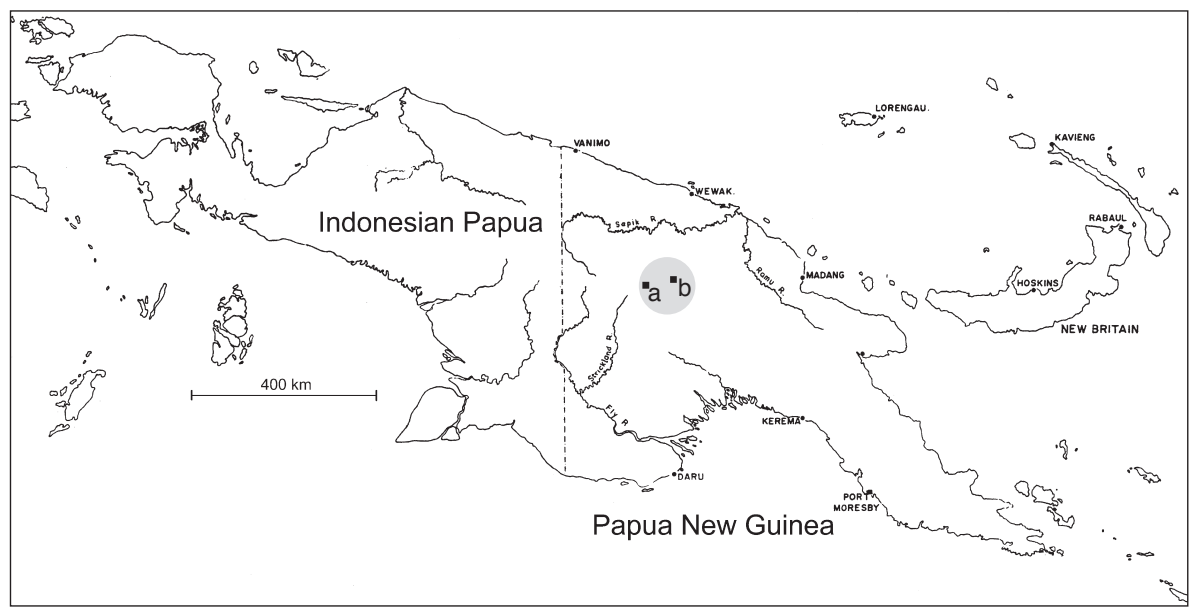

Map 1. Island of New Guinea. Localities from the Kaijende Expedition of 2005. a. Paiela (Lake Tawa); b. Porgera. 


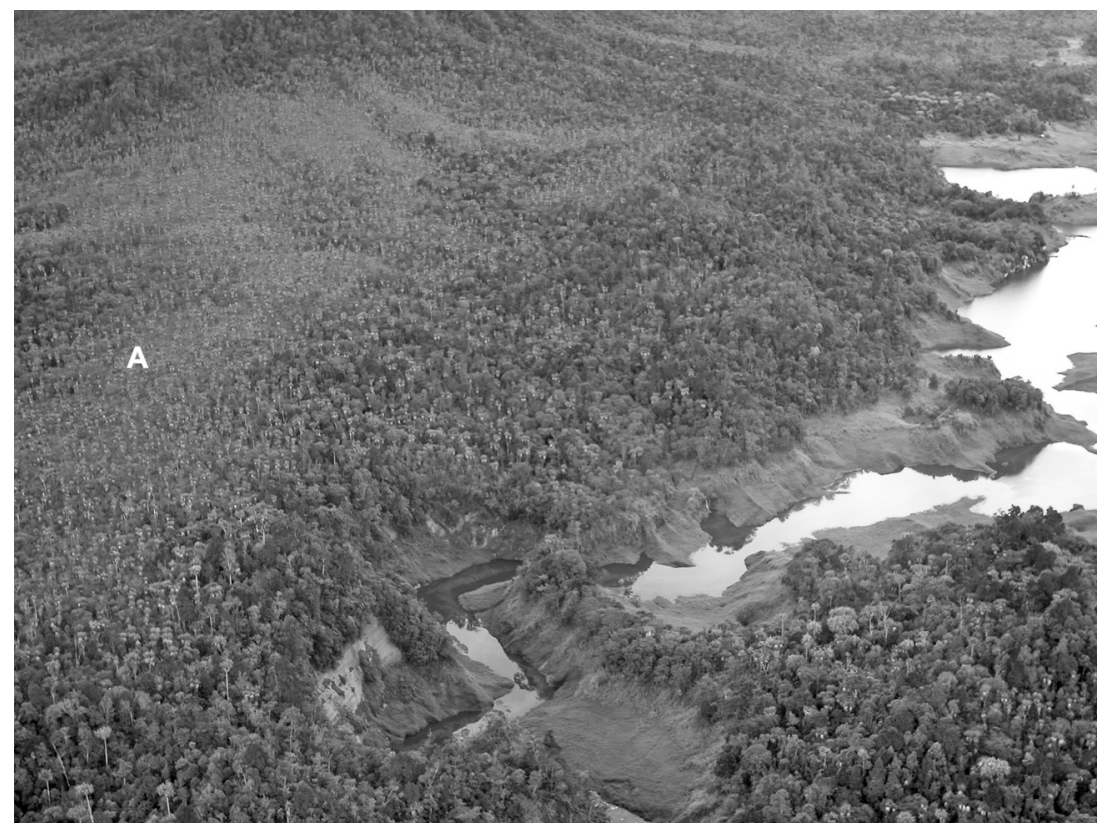

Fig. 3. Aerial perspective of the type locality at Lake Tawa. A. Pandanus savannah forms the lightcoloured vegetation on flat terrain.

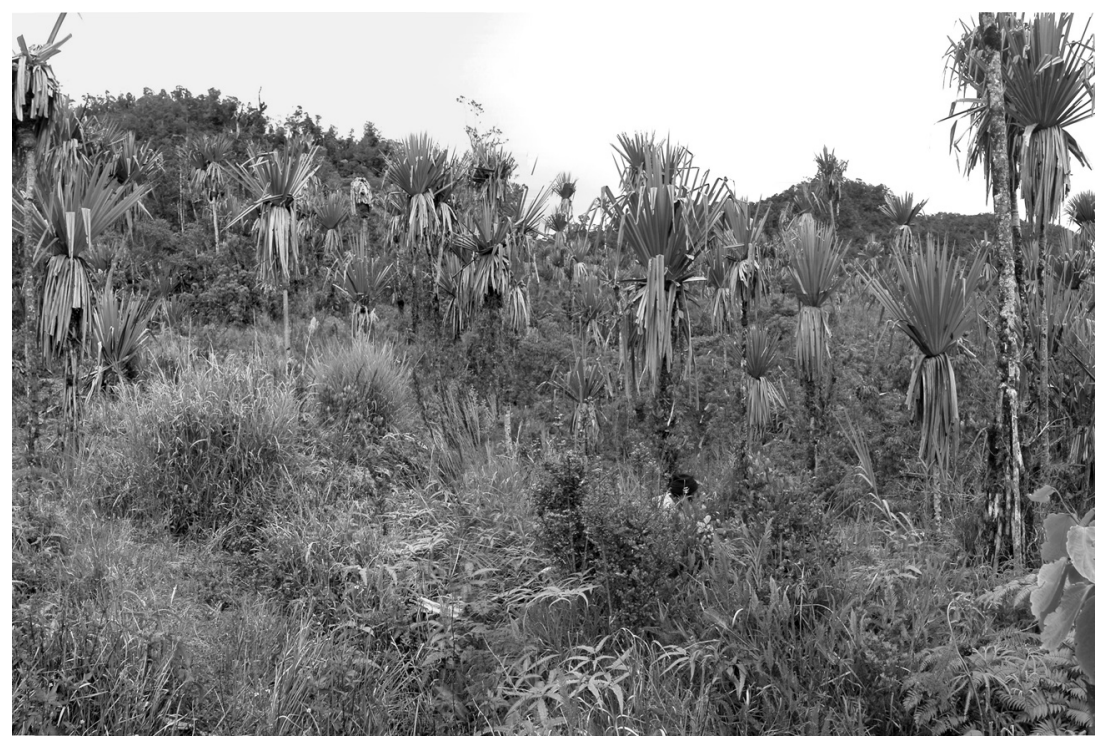

Fig. 4. Ground view of the Paiela savannah, principal habitat for Glochidion welzenii. The pandan communities are a previously-unrecorded vegetation facies. 
apically recessed, surmounted by the persisting style column; cocci 3 , retuse; seeds 2 per coccus, furnished with a red aril-like covering.

Distribution - Known only from the type locality in the Lake Tawa limestone district.

Habitat \& Ecology - Pandanus savannah on undulating tableland and in riparian fringes of closed-basin lakes, from 2450-2800 m elevation (Fig. 3-5).

Etymology - Peter van Welzen (L) is an authority on the Euphorbiaceae and a frequent contributor to our knowledge of the Malesian flora.

Notes - 1. Glochidion welzenii will key directly to couplet 21 (G. dumicola and G. oogynum) in Airy Shaw (1980: 95), but there are also apparent similarities with G. oblongifolium. The differentiating character states for these species are summarized in Table 1.

2. With microphyllous blades and retusely-notched trigonous fruits, Glochidion welzenii is reminiscent of Phyllanthus in aspect but is otherwise clearly a Glochidion. The novelty is easily distinguished from congeners by its small leaves and solitary flowers.

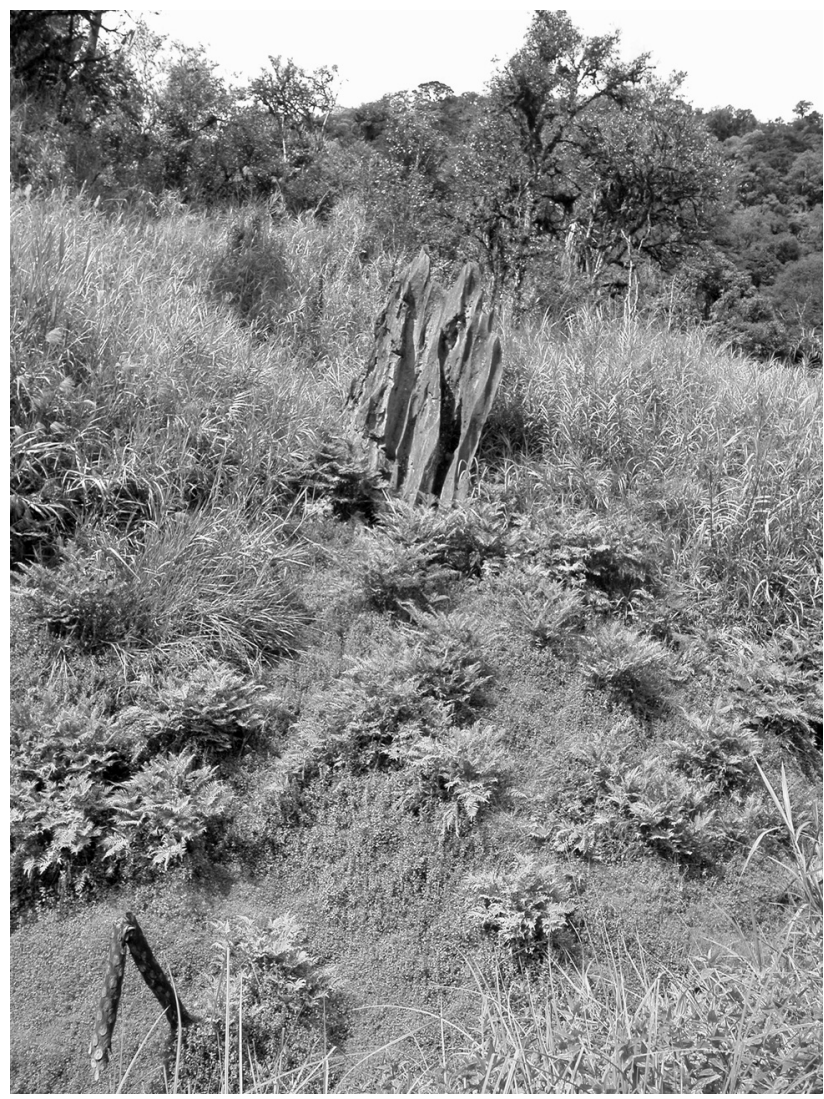

Fig. 5. Riparian community at Lake Tawa, collection site for Takeuchi, Towati \& Ama 20025. The tufted ferns (foreground) are Pteris wallichiana. Mischanthus floridulus forms a characteristic border along the forest margin. 
迎

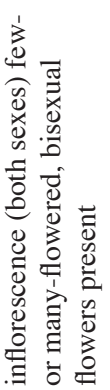

氜

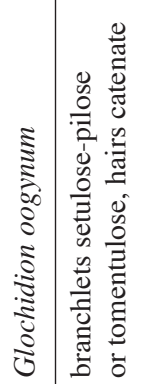

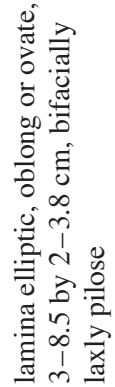

ป气

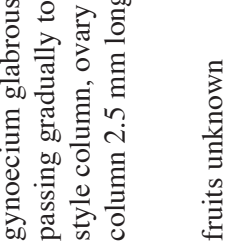

:

ปิ
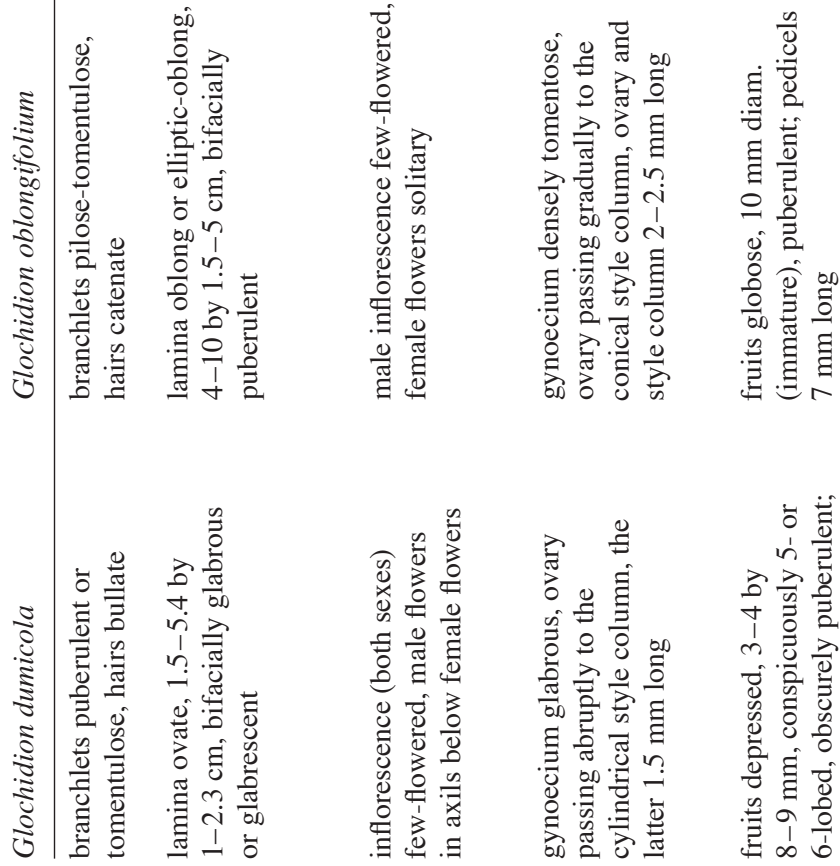
3. Papuasian Glochidion are disproportionately represented by large-leaved species with multilocular capsules (Airy Shaw 1972). The depauperate taxa such as G. welzenii are much fewer in number and rarely collected.

4. The type locality is surrounded to the north and west by extensive Pandanus savannah of a type untreated in existing systems of vegetation classification (e.g., Paijmans 1976). These unusual formations are associated with the presence of clay hardpans on undulating tableland, where impeded drainage results in surface waterlogging. Glochidion welzenii is a prominent component of such areas and occurs primarily in its open habitats.

No evidence of fire influence was seen during the survey, consistent with the presumption of a natural origin for the savannah. The oftentimes sharp and regular border between savannah and forest (without the wind-shaped grassy 'fingers' characteristic of fire), is also suggestive of a non-anthropogenic status. In the current forest classification system for Papua New Guinea (Hammermaster \& Saunders 1995a, b) the Paiela savannah is mapped as 'Gi' and 'Sc' (subalpine grassland and scrub, respectively) but is profoundly different in structure and composition from supposedly equivalent areas elsewhere in the Kaijende Highlands (e.g., in the Waile Creek-Omyaka district near Porgera).

5. Paiela is the largest remaining tract of uninhabited forest within the Highlands region. The need for long helicopter flights when accessing the interior has been largely responsible for the district's unexplored status. Several localities near Lake Tawa are distinguished by spectacular occurrences of doline karst (Löffler 1977), a landform characterized by impassable arrays of knife-ridge limestone. Despite the many discoveries made during the expedition, future exploration of this unique environment will be deterred by the difficulty and logistical costs of access.

Additional specimens examined:

PaPua New Guinea. Enga Province, Paiela bivouac, Takeuchi, Towati \& Ama 19806 (BISH, L, LAE), Pandanus-Dicranopteris savannah, 27 August 2005; Takeuchi, Towati \& Ama 19994 (A, K, L, LAE), lakefront at the second catchment, 31 August 2005.

\section{ACKNOWLEDGEMENTS}

The Kaijende Highlands Expedition was funded primarily by Conservation International and the Porgera Joint Venture (operators of the Porgera gold mine). My activities in Papuasian botany are supported by the National Science Foundation (exploration grant DEB 0315930), the Arnold Arboretum and the Herbaria of Harvard University.

The Kaijende assessment was organized by Stephen Richards (herpetologist, South Australian Museum) and Bruce Beehler (ornithologist, Conservation International). The faunal surveys also included Kristofer Helgen (mammalogist, South Australian Museum), and local counterparts Opon Naipao (Enga Provincial Government) and Robert Sine (PNG Department of Environment and Conservation). Parataxonomists Minau (Ali) Towati and Demas Ama were my principal associates in the field.

\section{REFERENCES}

Airy Shaw, H.K. 1972. Notes on Malesian and other Asiatic Euphorbiaceae. CLII. The genus Glochidion J.R. \& G. Forst. in New Guinea. Kew Bull. 27: 63-74.

Airy Shaw, H.K. 1980. The Euphorbiaceae of New Guinea. Kew Bull., Addit. Ser. 8: 1-243. 
Barthlott, W., W. Lauer \& A. Placke. 1996. Global distribution of species diversity in vascular plants: towards a world map of phytodiversity. Erdkunde 50: 317-328.

Barthlott, W., J. Mutke, D. Rafiqpoor, G. Kier \& H. Kreft. 2005. Global centers of vascular plant diversity. Nova Acta Leop. n.s. 92 (342): 61-83.

Hammermaster, E.T. \& J.C. Saunders. 1995a. Forest resources and vegetation mapping of Papua New Guinea. PNGRIS Publ. no. 4. CSIRO \& AIDAB, Canberra.

Hammermaster, E.T. \& J.C. Saunders. 1995b. Forest resources and vegetation mapping of Papua New Guinea. $1: 250,000$ vegetation map overlays separately issued as working copies to PNGRIS Publ. no. 4. CSIRO \& AIDAB, Canberra.

Löffler, E. 1977. Geomorphology of Papua New Guinea. CSIRO \& Australian National University Press, Canberra.

Paijmans, K. (ed.). 1976. New Guinea vegetation. CSIRO \& Australian National University Press, Canberra.

Richards, S.J. (ed.). 2007. A rapid biological assessment of the Kaijende Highlands, Papua New Guinea. RAP Bulletin of Biological Assessment 45. Conservation International, Washington DC.

Takeuchi, W. 2007. Vascular plants: taxonomic and vegetation survey. In: S. Richards (ed.), A rapid biological assessment of the Kaijende Highlands, Papua New Guinea. RAP Bulletin of Biological Assessment 45: 25-39, 71-86. Conservation International, Washington DC. 